Article

\title{
Increasing the Performance of an Adsorption Chiller Operating in the Water Desalination Mode
}

\author{
Karol Sztekler*(D) and Lukasz Mika (D) \\ Faculty of Energy and Fuels, AGH University of Science and Technology, Mickiewicza 30, 30-059 Krakow, Poland; \\ lmika@agh.edu.pl \\ * Correspondence: sztekler@agh.edu.pl
}

check for updates

Citation: Sztekler, K.; Mika, Ł. Increasing the Performance of an Adsorption Chiller Operating in the Water Desalination Mode. Energies 2021, 14, 7743. https://doi.org/ $10.3390 /$ en14227743

Academic Editor: Paweł Ocłoń

Received: 13 October 2021

Accepted: 12 November 2021

Published: 18 November 2021

Publisher's Note: MDPI stays neutral with regard to jurisdictional claims in published maps and institutional affiliations.

Copyright: (c) 2021 by the authors. Licensee MDPI, Basel, Switzerland. This article is an open access article distributed under the terms and conditions of the Creative Commons Attribution (CC BY) license (https:// creativecommons.org/licenses/by/ $4.0 /)$.

\begin{abstract}
The intensive development of the world economy and the expected population growth mean that demand for cooling and water will continue to rise. The use of conventional technologies to meet this demand is associated with an enormous expenditure of electricity, which still comes mainly from non-renewable sources. With the increasing demand for energy, the increasing scarcity of drinking water, and the negative impact of humankind on the environment due to global warming and ozone depletion, intensive research has been carried out to find modern desalination technologies Most of the technologies use electricity for the process of desalination, and over $6 \%$ of the world's electricity is generated from non-renewable sources, thus increasing the emissions of harmful pollutants into the atmosphere. One possibility to reduce emissions is the use of adsorption chillers with desalination function, which allow the production of cooling simultaneously with the process of water desalination. These systems can be powered by low-temperature waste heat from industrial processes or from renewable sources (solar panels) and require little electricity to operate. This paper presents options to improve their performance and increase the production of condensate in the process of desalination of saline water. Moreover, also presented are the results of tests carried out on a two-bed adsorption chiller with desalination function. The aim of the study was to determine the effect of cycle time on the cooling coefficient of performance (COP) and on the production of condensate from water desalination. The obtained results confirmed that increasing the adsorption and desorption cycle time leads to an increase in the COP value of the adsorption chiller, but the efficiency of the desalination process and condensate production decreases with increasing cycle time.
\end{abstract}

Keywords: adsorption; chiller; desalination

\section{Introduction}

It is estimated that over 100 million Europeans are at risk of experiencing a shortage of potable water. The problem of insufficient water resources affects approximately onethird of the European Union's area. Agriculture accounts for the highest use, at around $40 \%$ of annual consumption. The power industry and the mining and manufacturing industries consume $28 \%$ and $18 \%$, respectively. The lowest water consumption is generated by households, at around $12 \%$, giving an average of $144 \mathrm{~L}$ per inhabitant per day. Over $88 \%$ of freshwater consumed is obtained from rivers or groundwater resources. Climate change is having a significant impact on the amount of renewable freshwater sources available. Low precipitation and population growth have caused a decrease by $24 \%$ over the last 50 years. According to 2018 data, Europeans consume about 119 L of bottled water per year, and, with the continued popularization of water consumption, this value is bound to increase [1-3].

With the current estimated rate of world population growth, the demand for drinking water will increase by $55 \%$ globally. Many countries are already experiencing water resource deficits. About 785 million people have no or limited access to drinking water resources. Almost 51\% of them live in Africa. Despite this, $90 \%$ of the world's population 
(approx. 6.8 billion) had access to a basic drinking water supply in 2017. Compared with 2000, this figure is $8 \%$ higher. The largest increase was in rural areas, from $69 \%$ to $81 \%$ between 2000 and 2017. In sub-Saharan Africa, the number of people with access to drinking water increased from $46 \%$ to $61 \%$ between 2000 and 2017. In Europe and North America, this indicator remained unchanged at 99\%, and globally it was 90\% in 2017. Currently, about $41 \%$ of people live in areas affected by water scarcity. Projections indicate that by 2025 this number will increase, and even 3.5 billion people may live in areas at risk of water scarcity. It is expected that 33 countries in the world will be in an area at very high risk of water scarcity by 2040 [2,4-6].

Every year, water consumption increases by 1\%. According to 2015 data from the IDA (International Desalination Association, Topsfield, MA, USA), more than 300 million people worldwide use such a water source. In mid-2016, it was reported that almost 19,000 desalination plants produced 96.5 million $\mathrm{m}^{3}$ of distillate per day. Half of all the facilities were located in countries of the Middle East $[4,7,8]$.

By far, the largest amount of water used in desalination is currently sea water. This is followed by treatment of brine from deep strata, river water (purification), and wastewater. Currently, about $0.2 \%$ of total electricity consumption worldwide is used for water treatment. Desalination requires 8 to 10 times more energy than extracting water from its available resources. This is one of the reasons why the search is on for unconventional desalination methods based on ecological sources using equipment that has significantly lower energy requirements for desalination than the solutions already in use. Depending on the type of energy used, a desalination process (Figure 1) can be divided into [9,10]:

- $\quad$ electrical processes;

capacitive deionization (CDI);

electrodialysis/electrodialysis reversal (ED/EDR);

- mechanical processes;

mechanical vapor compression (MVC);

reverse osmosis $(\mathrm{RO})$;

nanofiltration (NF);

- $\quad$ thermal processes

multi-stage flash distillation (MSF);

multi-effect distillation (MED);

thermal vapor compression (TVC);

humidification dehumidification (HDH);

membrane distillation (MD); and

adsorption desalination (AD).

Today, the dominant technology used for desalination is reverse osmosis (RO), which is used to desalinate more than $60 \%$ of the world's water. The next most widely used methods for desalination are multi-stage flash distillation (MSF) and multi-effect distillation (MED). The distillation process involves applying heat energy to water, resulting in a change in its state of matter. Water vapor is completely devoid of mineral salts and condenses into desalinated water. In the multi-stage flash distillation (MSF) process, saline water is heated to produce vapor, which is then condensed to produce fresh water. At lower pressures, water boils at lower temperatures, which increases the efficiency of the process and reduces its cost. Another method used in water desalination is multi-effect distillation (MED). In this technology, the saline water passes through evaporators, pressurized vessels with increasingly lower temperatures and pressures. In this system, the water vapor from one evaporator is used to evaporate the liquid in the next one. Reverse osmosis is the most commonly used process for desalinating water. In this process, the driving force is the pressure difference between the two sides of a membrane. The membranes used for the reverse osmosis process are permeable to water and impermeable to salt. Another method that is also very important in the water purification technology market is the adsorption method, which is an excellent alternative to the RO, MED, and MSF due to its efficiency 
in terms of the amount of electricity used in the desalination process. What is more, desalination by the adsorption method allows for efficient use of waste heat and heat from renewable sources. Hot water from solar collectors is used as the driving energy for the adsorption system operation. Desalination based on the adsorption effect is a technology addressing one of the most significant civilization problems of the 21st century, i.e., the need to save energy resources and protect the environment, so interest in this technology is high $[11,12]$.

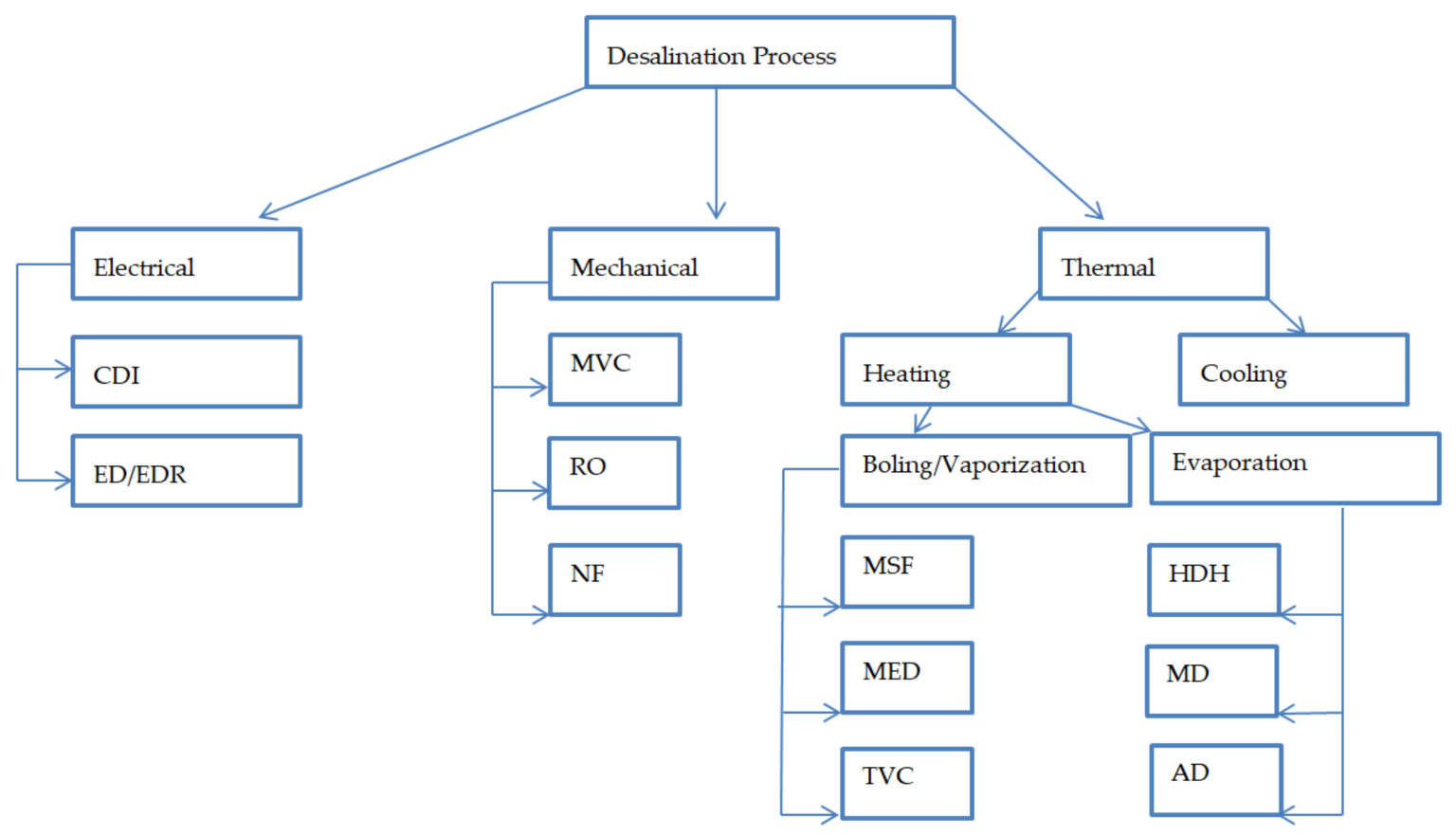

Figure 1. Division of desalination methods $[9,10]$.

Table 1 presents a comparison of parameters characterizing the selected most popular desalination technologies and the adsorption desalination technology. It should be noted here that the method of adsorption desalination uses mostly free thermal energy, which is not the case with most conventional methods. For a full comparison of the energy demands between the different technologies, it should also be classified into paid and free energy. The energy consumption values should also be related to the theoretical thermodynamic limit of the desalination process of $0.78 \mathrm{kWh} / \mathrm{m}^{3}$ [11].

Table 1. Comparison of characteristic parameters of selected desalination technologies.

\begin{tabular}{|c|c|c|c|c|c|}
\hline $\begin{array}{l}\text { Desalination } \\
\text { Technology }\end{array}$ & $\begin{array}{l}\text { Electricity Consumption } \\
{\left[\mathrm{kWh} / \mathrm{m}^{3}\right]}\end{array}$ & $\begin{array}{c}\text { Heat Energy } \\
\text { Consumption }\left[\mathrm{kWh} / \mathrm{m}^{3}\right]\end{array}$ & $\begin{array}{c}\text { TDS in Produced } \\
\text { Water } \\
\text { [ppm] }\end{array}$ & $\begin{array}{l}\text { Cost of Water } \\
{\left[\$ / \mathrm{m}^{3}\right]}\end{array}$ & Source \\
\hline $\mathrm{AD}$ & $\begin{array}{c}<1.5 \\
1.38^{*}\end{array}$ & $38.8^{*, * *}$ & $<10$ & 0.2 & [13-15] \\
\hline MSF & $\begin{array}{l}3.5-5 \\
5.2^{*} \\
1.5-5\end{array}$ & 57.14 * & $\sim 10$ & 1.07 & {$[13,14,16]$} \\
\hline MED & $\begin{array}{l}3.8^{*} \\
2^{*}\end{array}$ & 43.21 * & $\sim 10$ & 0.83 & {$[11,13,14,16]$} \\
\hline SWRO & $\begin{array}{c}3-4 \\
3.71^{*}\end{array}$ & 0 & $200-500$ & 1.1 & {$[7,12,13,17]$} \\
\hline MED-AD & $1.94^{*}$ & 16.14 * & $<10$ & 0.26 & {$[11,18]$} \\
\hline
\end{tabular}

${ }^{*}$ Examples of values found in the literature. ${ }^{* *}$ Waste heat. 
Of the desalination methods shown in Table 1, the MSF technology contributes the most, and the adsorption technology, the least to $\mathrm{CO}_{2}$ emissions per $\mathrm{m}^{3}$ of desalinated water [13]. It is anticipated that by 2050 carbon dioxide emissions from desalination processes alone will be 0.4 billion tonnes per year. This is a serious constraint to their development. An interesting and prospective solution to this problem might be the use of renewable energy sources for desalination. Another modern approach to reducing energy consumption is the use of advanced membranes characterized by very high permeability. The amount of energy required for the desalination process can vary and depends on, among other things, the desalination technology used, the degree of desalination required, and the source and contamination of the feed water. The most energy is required to desalinate seawater [19]. However, high electricity consumption is not the only disadvantage of the conventional desalination technologies. These also include high maintenance costs as well as pollution and erosion, and even clogging of the exchangers and membranes. Another major problem is corrosion of the components exposed to saline water. The need for chemical water treatment before and after the desalination process is also a drawback $[17,20]$.

An alternative to the commonly used desalination methods is the use of sorption technologies, which also allows the use of medium-temperature waste heat for the production of distilled water or/and 'cooling' and is characterized by the lowest demand for electricity compared with other technologies. Sorption technologies include adsorption (based on hot water with a temperature in the range $55-90^{\circ} \mathrm{C}$ ), which is necessary for sorbent regeneration. An important feature of adsorption devices is the operation in near-vacuum conditions, which enables water evaporation with a significantly lower energy input compared with classical evaporation methods. Another advantage of sorption devices is the option of cascade installation, thanks to which the heating medium, after giving up its heat in another sorption device and cooling down, has the right temperature to supply another adsorption device. Thanks to this, the sorption technology is able to use the energy contained in the medium heated by waste heat or coming from renewable energy sources very effectively. Adsorption desalination devices have many advantages, such as no moving parts, the option of operating with hot water temperatures from $55^{\circ} \mathrm{C}$ and above, and low consumption of electricity and heat for the desalination processes. Disadvantages include low desalination capacity, COP efficiency of the device at 0.6, and bulky dimensions. The performance of an adsorption chiller with desalination function and the size of the desired effect depend on many factors. An improvement in the performance of the device can be achieved by:

- Modification of the adsorption/desorption cycle time;

- Increasing the efficiency of heat exchange in the bed between exchanger and sorbent;

- Increasing the sorbent regeneration temperature;

- Changing the design of the bed exchanger; and

- Using new adsorbents with higher sorption capacity [21].

In this work, the main focus was on improving performance by means of changing the adsorption-desorption cycle time. Increased performance will make it possible to gradually reduce the size and weight of adsorption chillers with desalination function. This means that they will become more attractive and competitive in the market. The efficiency of a chiller is described in terms of its COP (coefficient of performance). The physical representation of the $C O P$ value is the ration of the heat absorbed in the evaporator and the heat supplied in order to carry out the desorption process and heat the bed [22]:

$$
C O P=\frac{Q_{p}}{Q_{d}+Q_{o}}
$$

where $Q_{p}$ is the heat absorbed in the evaporator, $Q_{d}$ is the heat supplied in the desorption process, and $Q_{o}$ is the heat delivered while heating the bed. 
Another important indicator describing the performance of a chiller is the SCP. It defines the efficiency in relation to the mass of the adsorbent. As the $S C P$ value increases, so does the cooling capacity for a specified amount of sorbent, thus reducing the size of the device by using less sorbent material $[16,23]$.

$$
S C P=\int_{0}^{t_{c y c l e}} \frac{Q_{p}}{m_{a}} d t
$$

where $m_{a}$ is the total mass of the sorbent and $t_{c y c l e}$ is the cycle time.

SCP strongly depends on the cooling water temperature. It increases when a lower temperature is reached in the condenser [21,24,25].

In desalination processes the daily water production is also particularly important. It specifies the amount of desalinated water, which very often is given in relation to the adsorbent mass in the unit per day [11]. One such option is the use of adsorption chillers for desalination of water. Using saline water as adsorbate, after condensation in the condenser, purified and desalinated water is obtained, almost free of dissolved solids [17].

The paper presents the results of experimental tests conducted for a laboratory threebed adsorption chiller with desalination function, in which the second and third beds were synchronized and carried out the same adsorption or desorption processes at the same time while the first bed worked in the opposite phase. In this study, a comprehensive experimental study for a two-bed adsorption chiller with a desalination function was performed. The influence of adsorption and desorption cycle times at different temperatures of the hot, cooling, and chilled water on chiller efficiency and distillate production was analyzed. Tests were performed using a device that allowed us to simulate the device's operation under various operating conditions. The obtained data will enhance a more efficient operation of the device with the highest efficiency and will allow determining the operating characteristics of the device at various operating conditions. Based on the literature review presented, it seemed that the research on the two-bed adsorption chiller was necessary and justified due to the following reason: Two-bed chillers are less complicated than four-bed and three-bed chillers. In the literature we can find studies of a desalination unit with adsorption device, where the distillate production is above $4 \mathrm{~m}^{3} /$ day and it is needed to carry out tests also on units with smaller capacity; adsorption chillers can operate in desalination and cooling modes or produce both chilled water and distillate. In the case of a single-family house with up to $20 \mathrm{~kW}$ of cooling capacity, the unit worked in a two-bed configuration; so, further research on the possibilities for increasing the efficiency of these chillers is essential. The study was designed to test the effect of cycle time on the value of the cooling coefficient of performance (COP) and the condensate production.

\section{Materials and Methods}

\subsection{Experimental Set-Up}

A key problem regarding adsorption devices is to optimize the operation of the cooling system with desalination function in the context of increasing the efficiency of water desalination. The tests concerning the operation of an adsorption chiller that can operate in either a cooling or a desalination mode were carried out on a device located at the Energy Centre of the AGH University of Science and Technology in Krakow. A detailed description of this test stand can be found in the following papers: [24,25]. This system had three beds, and tests can be carried out for a single-bed, a two-bed, and a threebed chiller. For the purpose of this paper, two beds were used in the adsorption chiller. The experimental results were used to determine the operating parameters of the chiller and the possibility of maximizing its performance under different operating conditions. From a functional point of view, a two-bed adsorption chiller consisted of the following three circuits:

Hot water circuit (supply circuit);

Cooling water circuit; and

Chilled water circuit (refrigeration circuit). 


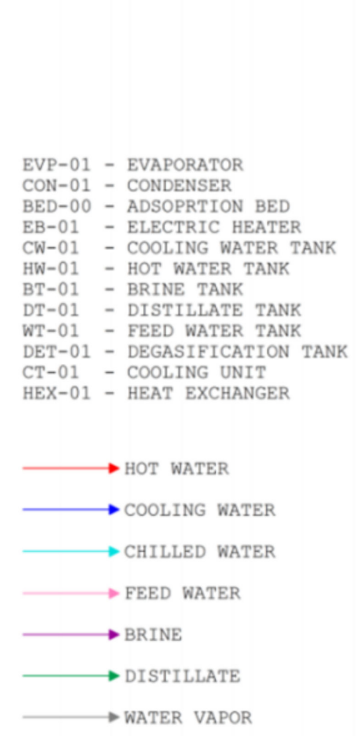

The chiller sequence of the operation consisted of four consecutive phases: (1) desorption/adsorption, (2) heat recovery, (3) adsorption/desorption, and (4) regeneration.

In Phase 1 (desorption/adsorption) hot water flowed through the desorber (Circuit 1). This way, the refrigerant (water) that accumulated on the inner surface of the silica gel was transported to the condenser and condensed. The heat generated during the condensation of the water was discharged through the cooling water circuit (Circuit 2). In Phase 2 (heat recovery), immediately after Phase 1 , the three-way diverter valves were set so as to allow heating water to flow through the previously desorbed adsorber. The heat energy accumulated in the adsorber was not immediately discharged out of the system but was transferred for a period of time to the hot water/heat source circuit. In Phase 3 (adsorption/desorption), the heat released during adsorption was discharged through the cooling water circuit together with the heat from condensation. This phase was completed as soon as the required temperature of the cooling water was reached. In Phase 4 (regeneration), immediately after Phase 3, the three-way diverter valve was set so as to allow the hot water required for the desorption phase to flow through the previously adsorbed adsorber. This water was pumped for a period of time into the cooling water circuit until the set temperature was reached. A diagram of the operation of the adsorption device is shown in Figure 2 the view of the adsorption chiller with all the components is shown in Figure 3.

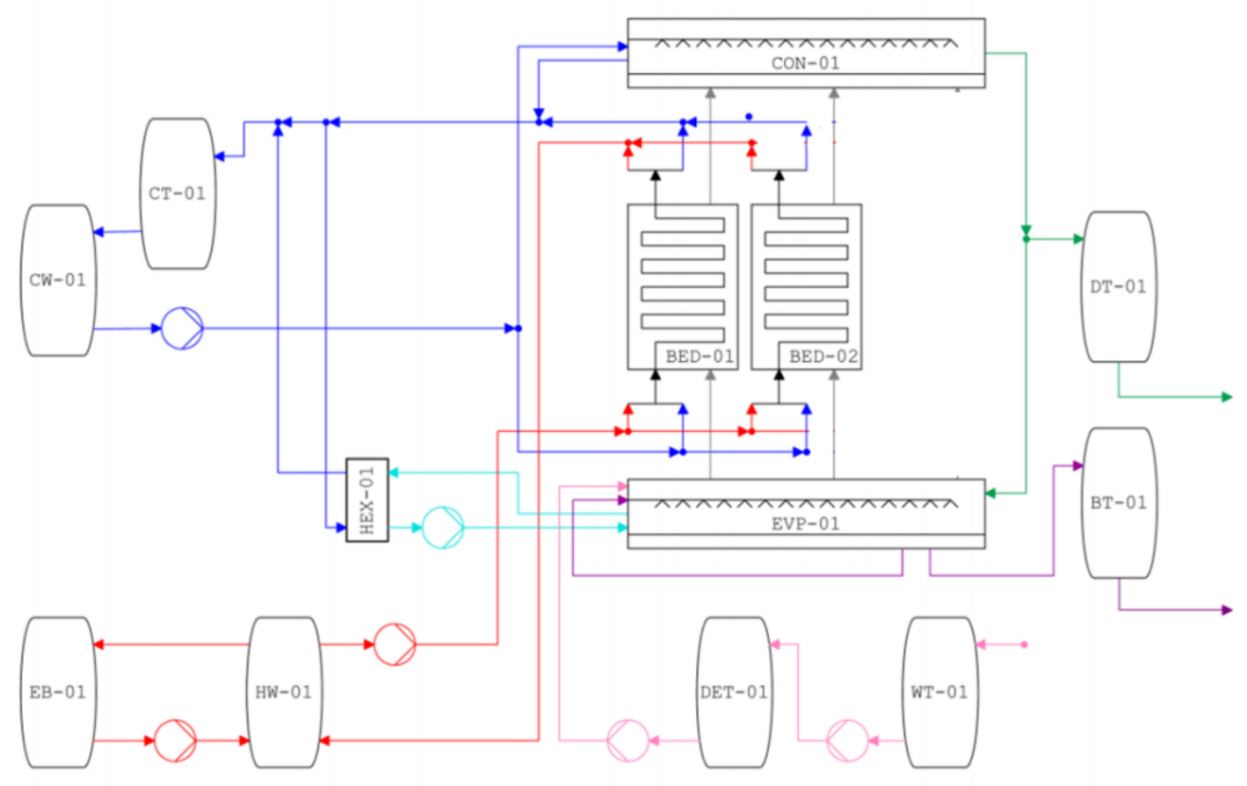

Figure 2. Two-bed adsorption chiller with desalination function.

The adsorption chiller with desalination function installed at the Energy Centre of the AGH University of Science and Technology was designed to operate in two modes: Cooling and Desalination. 


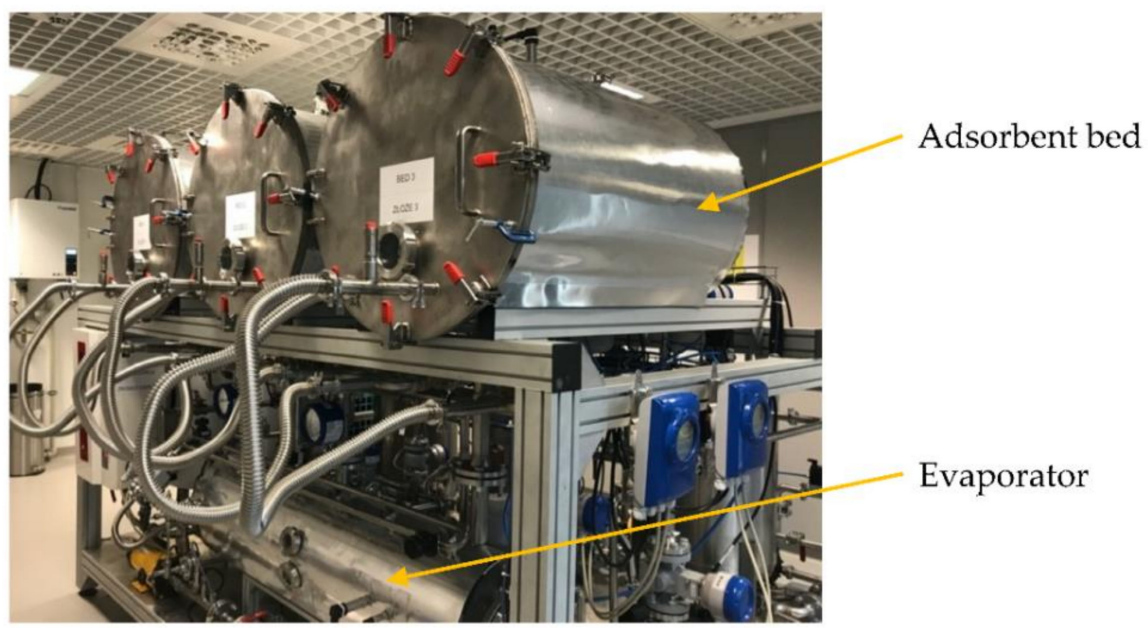

(a)

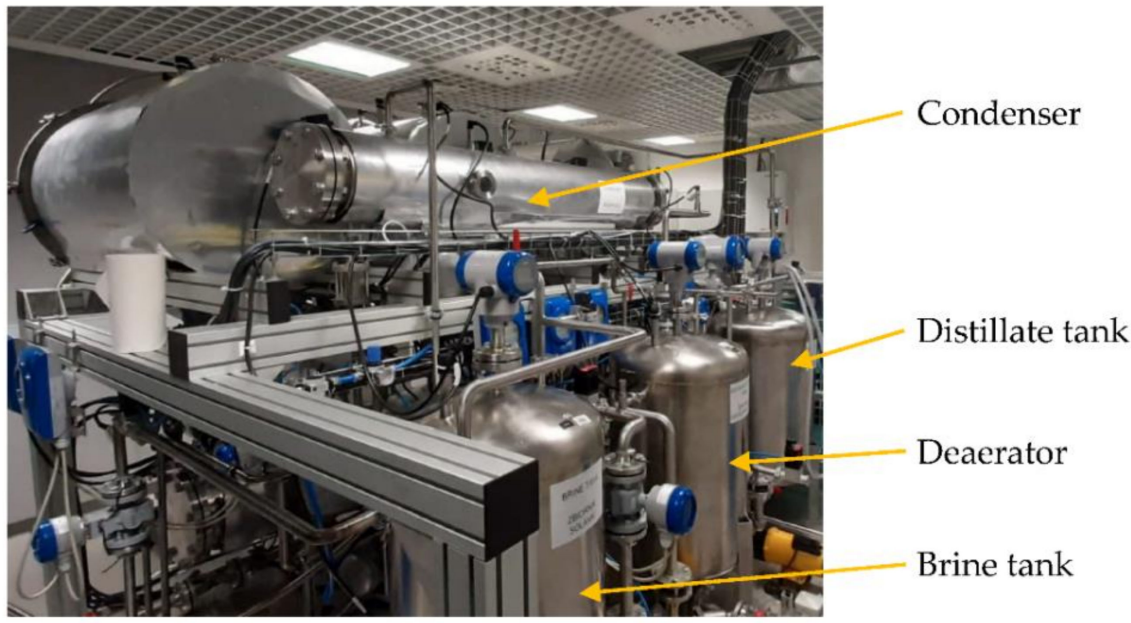

(b)

Figure 3. Pictures of the test stand: (a) view of evaporator and adsorption bed; (b) view of the condenser, distillate tank, deaerator tank, and brine tank.

\subsection{Cooling Mode}

In this mode, chilled water will be produced in the evaporator. The chilled water produced will lower the temperature of the chilled water circuit, simulating a cooling consumer. During operation, the refrigerant vapors formed in the evaporator are absorbed by the adsorption bed due to the hygroscopic properties of the sorbent. After the bed becomes fully saturated with vapor, it is separated from the evaporator and switched to the desorption mode, i.e., the previously adsorbed water is evaporated and vapor is supplied to the condenser. The fully regenerated bed will be ready again for the adsorption phase after first being cooled. The condensed vapors in the condenser will be fed back to the evaporator.

\subsection{Desalination Mode}

In this mode, desalinated water will be produced. The chilled water circuit will be used as a cooling source for the condenser. This is done through the evaporator-condenser heat recovery system. The condensation heat of the refrigerant will be transported from the condenser to the evaporator and then used to evaporate the refrigerant. The water cooled in the evaporator will be transported back to the condenser so as to form a closed circuit and relieve the load on the bed cooling system and the condenser. The brine, previously deaerated, will be 'heated' in the evaporator, where pure water vapor will evaporate (with a very low salt content characterizing the product after condensation as distilled water). 
The liquid that is not evaporated will be discharged into the brine tank when the limit of solids' content is exceeded (based on conductivity measurement).

The main parameters of the adsorption chiller with desalination function are shown in Table 2.

Table 2. Main parameters of the adsorption chiller with desalination function installed at the Energy Centre of the AGH University of Science and Technology.

\begin{tabular}{cccc}
\hline & Parameter & Value & Unit \\
\hline \multirow{4}{*}{ Evaporator } & Cooling capacity & 1.10 & $\mathrm{~kW}$ \\
& Chilled water inlet temperature & 12 & ${ }^{\circ} \mathrm{C}$ \\
& Chilled water outlet temperature & 7 & ${ }^{\circ} \mathrm{C}$ \\
& Chilled water mass flow & 0.0523 & $\mathrm{~kg} / \mathrm{s}$ \\
\multirow{2}{*}{ Condenser } & Capacity & 2.00 & $\mathrm{~kW}$ \\
& Cooling water inlet temperature & 20 & ${ }^{\circ} \mathrm{C}$ \\
& Cooling water outlet temperature & 22 & ${ }^{\circ} \mathrm{C}$ \\
& Cooling water mass flow & 0.250 & $\mathrm{~kg} / \mathrm{s}$ \\
\hline
\end{tabular}

The device uses a measuring system that includes temperature, pressure, and flow rate measurements. Table 3 shows the characteristics of the measuring instruments.

Table 3. Parameters of the measuring instruments.

\begin{tabular}{ccc}
\hline Instrument & Operating Range & Accuracy \\
\hline Temperature sensor PT- 1000 & $-80{ }^{\circ} \mathrm{C}$ to $150{ }^{\circ} \mathrm{C}$ & $0.1{ }^{\circ} \mathrm{C}$ \\
Pressure transducer & $0-99 \mathrm{kPa}$ & $0.50 \%$ \\
Electromagnetic flow meter & $1-100 \mathrm{~L} / \mathrm{min}$ & $0.50 \%$ \\
\hline
\end{tabular}

During the experimental tests, all measurements were taken every $5 \mathrm{~s}$ using the SCADA control system and stored on a personal computer and then imported into Microsoft Excel. All the pumps and valves could be controlled at the test stand, and it was possible to set the duration of each phase of operation of the device. The system was complete with manual ball valves and pneumatic valves located between the evaporator and the beds, and between the condenser and the beds. In order to force flow into the individual circuits of the device, pumps with a capacity of $0-500 \mathrm{~L} / \mathrm{h}$ were installed.

\subsection{Operating Conditions}

Duration of each phase in the sequence of operation of the device and its configuration could be set individually for each bed at the test stand. The experimental tests were performed in two stages. The first stage examined the effect of changes in the hot water temperature on the COP and SCP values found for the chiller. In this stage, the chiller operated without water desalination; so, it was possible to obtain the maximum values of COP and SCP for the device. In the second stage of the testing, the operating conditions of the chiller, at which it reached the highest values of these indices, were selected to examine the effect of the duration of the particular sequences of operation of the device on the COP value and the quantity of purified water at constant value of the hot water temperature. During the second stage of testing this system, the desalination process was carried out in an open system, and the resulting condensate was not recirculated back into the evaporator but deposited in an external tank (simultaneous production of desalinated water and chilled water). Brine was fed to the evaporator from an external tank so that a constant brine level could be ensured in the evaporator, allowing the system to operate under the same conditions regardless of the amount of desalinated water. Adsorption beds filled with silica gel sorbent from KD Corporation, in the form of loosely arranged granules with particle sizes in the range of $700-800 \mu \mathrm{m}$, were used in the tests. A finned coil heat exchanger was installed in the adsorption bed. 
During the first stage of the experiment, the effect of the hot water temperature used for bed regeneration in the desorption process on the COP and SCP of the device was investigated. In the case analyzed, the hot water temperature was changed in the range of $55-85^{\circ} \mathrm{C}$. In this phase, tests were carried out on a two-bed system at a set outlet chilled water temperature of $15^{\circ} \mathrm{C}$ and a cooling water temperature of approx. $20^{\circ} \mathrm{C}$. During the first phase of the experiment, i.e., tests without desalination, the duration of each phase was set based on the previous experiments at the following levels: regeneration, $50 \mathrm{~s}$; adsorption/desorption, 350 s; heat recovery, 30 s; regeneration, 50 s; adsorption/desorption, $350 \mathrm{~s}$; and heat recovery, $30 \mathrm{~s}$. The results from the tests in the first stage provided the guidelines for the performance of tests in the second stage. Experiments in the second stage were carried out at electrical conductivity of the water fed into the evaporator of approx. $40 \mathrm{mS} / \mathrm{cm}$. The desalinated water produced had an electrical conductivity of $0.07 \mathrm{mS} / \mathrm{cm}$, which corresponded to the parameters of distilled water, while the electrical conductivity of the concentrated brine in the evaporator at the end of the experiment was about $60 \mathrm{mS} / \mathrm{cm}$.

For proper operation of an adsorption chiller with desalination function, it was required to adjust all water flows to achieve a desired performance of the unit. The change of water flow in one of the circuits forced modifications in the other circuits (temperature and flow rate), as well. Thus, before starting the experimental tests, the device was subjected to a regulation process. The device must be operated for quite a long time to achieve stable operating parameters. Changing the flow rate of any of the water flowrates affected both the amount of condensate produced and the output of the condenser and evaporator. For example, if the cold water flow rate in the evaporator is reduced, a smaller desalination capacity is achieved; but, if the hot water flow rate is maintained at the same level and temperature conditions, the desorption cycle time will be much shorter. This is due to the ability to adsorb a smaller amount of water available under these conditions. Therefore, the required cycle time of the sorption process will also change. Changes in the water mass flowrate affect the cycle time of the device and, consequently, the performance of the entire device. However, another research challenge, undertaken for the first time in this paper, was to determine the optimal cycle time at which the operating parameters of the device were maximized under given operating conditions and bed design while condensate production was maximized. In adsorption chillers operating in an automatic mode, the work cycles may be excessively shortened or lengthened. The intensity of sorption processes does not change linearly and there is some difficulty in optimum cycle time determination, especially when the chiller works with desalination function at the same time. The intensity of condensate production also varies non-linearly with time, which further complicates the adoption of appropriate unit settings. Since the sorption processes depend on many variables, the water flow rates in the individual circuits of the device were determined and their temperatures were fixed. The aim of the research in this paper was to obtain the characteristics of the device in the scope of the influence of cycle time changes for the given temperature levels of cooling, hot, and ice water on the COP of the device and the distillate production volume.

Table 4 presents the experimental study design for the determination of the performance characteristics of the adsorption chiller operating in desalination mode depending on the times of the adsorption and desorption processes. The research work was divided into three groups that differed with regard to the temperatures of the water cooling the condenser and of chilled water, with one hot water temperature fixed in the first stage of the study. The condenser cooling water temperatures and chilled water temperatures in each test group were $20^{\circ} \mathrm{C}, 25^{\circ} \mathrm{C}$, and $30^{\circ} \mathrm{C}$, and $15^{\circ} \mathrm{C}, 20^{\circ} \mathrm{C}$, and $25^{\circ} \mathrm{C}$, respectively. For each group, experimental tests were carried out to determine the characteristics of the COP and the condensate (desalinated water) produced. In Table 4 the cycle times of regeneration, sorption, and heat recovery were proposed based on the previous experience of the authors of this work. For the sorption cycle time optimization, six different cycle times at different temperatures of hot, cooling, and chilled water were proposed. The 
cycle times of regeneration and heat recovery resulted from the technical parameters of the heat exchanger in the adsorption bed, which mainly depended on its heat capacity and water capacity.

Table 4. Stage 2, experimental study design.

\begin{tabular}{cccc}
\hline & Group 1 & Group 2 & Group 3 \\
\hline Hot water temperature $\left[{ }^{\circ} \mathbf{C}\right]$ & 80 and 65 & 80 and 65 & 80 and 65 \\
Cooling water temperature $\left[{ }^{\circ} \mathbf{C}\right]$ & 20 & 25 & 30 \\
Chilled water temperature $\left[{ }^{\circ} \mathbf{C}\right]$ & 15 & 20 & 25 \\
& $50 / 150 / 30 / 50 / 150 / 30$ & $50 / 150 / 30 / 50 / 150 / 30$ & $50 / 150 / 30 / 50 / 150 / 30$ \\
Cycle times [s]: & $50 / 250 / 30 / 50 / 250 / 30$ & $50 / 250 / 30 / 50 / 250 / 30$ & $50 / 250 / 30 / 50 / 250 / 30$ \\
(regeneration/sorption/heat & $50 / 350 / 30 / 50 / 350 / 30$ & $50 / 350 / 30 / 50 / 350 / 30$ & $50 / 350 / 30 / 50 / 350 / 30$ \\
recovery/regeneration/sorption/heat recovery) & $50 / 450 / 30 / 50 / 450 / 30$ & $50 / 450 / 30 / 50 / 450 / 30$ & $50 / 450 / 30 / 50 / 450 / 30$ \\
& $50 / 550 / 30 / 50 / 550 / 30$ & $50 / 550 / 30 / 50 / 550 / 30$ & $50 / 550 / 30 / 50 / 550 / 30$ \\
& $50 / 700 / 30 / 50 / 700 / 30$ & $50 / 700 / 30 / 50 / 700 / 30$ & $50 / 700 / 30 / 50 / 700 / 30$ \\
\hline
\end{tabular}

\section{Results and Discussion}

Experimental studies carried out in a desalination adsorption chiller will enable determining the effect of hot water temperature on the COP and SCP coefficients of the chiller. The experimental data obtained will provide valuable knowledge needed for a more detailed study of the effects of time and temperature of the hot water and cooling water on the efficiency of the chiller and the production of distillate in the desalination process. At the AGH University of Science and Technology, the adsorption chiller was designed to examine the improvement of cooling and desalination efficiency. The chiller with desalination function allows for very precise measurements related to the improvement of unit efficiency in different operating modes and configurations with variable parameters of chilled and cooling water and also for different times of individual unit operation cycles. It is very specific equipment working in such a configuration, but similar studies were also carried out in other research centers. The influence of cycle time on COP was also investigated by Saha et. al. [26]. In this study, the highest value of COP was obtained for the adsorption/desorption cycle time equal to 180-300 s. Another paper [26] included a simulation study using a simulation computer software to analyze the influence of operating temperatures (hot and cooling water temperatures, adsorption/desorption cycle time) on COP for three-bed, cycle adsorption chillers. The results showed an increase in COP as a function of the hot water temperature; so, for temperatures of $60{ }^{\circ} \mathrm{C}$ and $90^{\circ} \mathrm{C}, \mathrm{COP}$ was about 0.28 and 0.38 , respectively. The calculations were performed using a simulation software; the study did not include the desalination process or a study of the effect of time and temperature of the chilled and cooling water on desalination efficiency. Pan et al. [27] experimentally investigated the influence of the heating water temperature on the efficiency of the two-bed adsorption chiller. In this paper, a study was conducted on a two-bed chiller without desalination and did not include an analysis of the effect of changing the cycle time on the efficiency of the unit. However, the study did confirm an increase in COP as a function of hot water temperature and for temperatures of 51.4-61.3 ${ }^{\circ} \mathrm{C}$, with the COPs from $0.285-0.47$. The studies described in $[26,27]$ presented the experimental results of the adsorption chiller, which were performed at constant conditions of the medium flow rate (cooling water, hot and cold). Presenting the experimental studies in this way allowed comparing the results by different authors. There are few works that have investigated the effect of water amount in the evaporator on the performance of the device. Kim et al. [28] investigated the quality of water produced in the four-bed adsorption chiller with distillate production of about $6 \mathrm{~m}^{3} /$ day. This paper focused on the effect of the filling degree of the evaporator with brine on the desalination efficiency. The chiller operation was studied for one temperature, $65^{\circ} \mathrm{C}$, chilled water inlet temperature of $20^{\circ} \mathrm{C}$, cooling water inlet temperature of $30^{\circ} \mathrm{C}$, and for time of cycle of $660 \mathrm{~s}$. In this case, the authors modified the evaporator brine fill rate, but kept the water flow rate in 
each circuit constant. Based on the literature review, it can be concluded that most of the studies related to the analysis of the operation of the adsorption chiller, operating in the desalination and cooling mode, were carried out for a constant water flow rate at varying operating temperatures of the device. The results showed a correlation between the variation of the water flow rate and the sorption cycle time; however, for each chiller tested under different operating conditions, optimal sorption cycle times, which also depend on the bed design, needed to be found.

During all the tests presented in this paper (combined, Stages 1 and 2), the adsorption chiller generated chilled water with an outlet flow temperature ranging from 8 to $25^{\circ} \mathrm{C}$ with a maximum temperature difference between the evaporator chilled water inlet and outlet flows of up to $2.5^{\circ} \mathrm{C}$.

In the case of condenser operation, the temperature difference between the inlet and outlet cooling water reached a maximum of approx. $2{ }^{\circ} \mathrm{C}$, and the inlet temperature of the condenser cooling water varied in the range of $15-30^{\circ} \mathrm{C}$. Presented below is an example of experimental data showing changes in the temperature and flow pressure in the components of the adsorption chiller with desalination function operating in the $50 / 350 / 30 / 50 / 350 / 30$ configuration for a hot water temperature of $85^{\circ} \mathrm{C}$ and a chilled water temperature of $15^{\circ} \mathrm{C}$.

The pressure variation curve presented in Figure 4 shows only an exemplary fragment of the experimental tests. The adsorption chiller worked in sequential changes in the pressure level, e.g., just after changing the operating cycle, the pressure in the beds increased from a certain initial value, and then their maximum, minimum and average values stabilized. Figure 5 presents changes in temperature of the evaporator, condenser, and beds in the adsorption chiller during the experimental investigations.

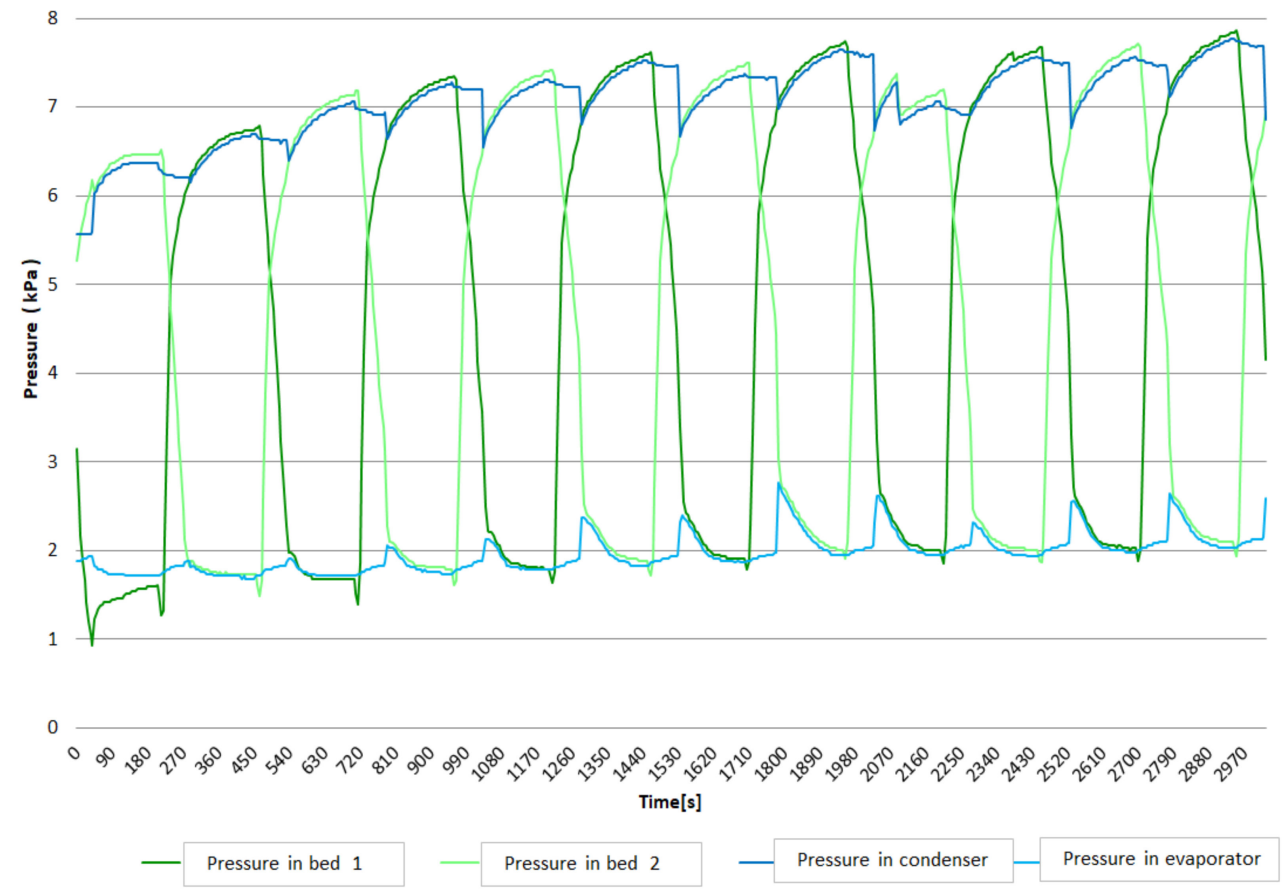

Figure 4. Changes in pressure in the adsorption chiller components during the testing.

Figure 6 shows an example of the temperature and water flow rate distribution in the chilled, cooling, and hot water circuits of the adsorption chiller. The experimental study was carried out with constant circulating water flows in the chiller. The temperature of the water in the evaporator depended on the pressure in it. A pressure value of $1.83 \mathrm{kPa}$ corresponded to an average evaporator temperature of approx. $15^{\circ} \mathrm{C}$, and for a pressure of $2.15 \mathrm{kPa}$, the temperature inside the evaporator was $18^{\circ} \mathrm{C}$. The temperature changes in the evaporator were due to the cyclic nature of the processes occurring in the device, and were 
primarily related to the cycles of adsorption and desorption of water vapor in the beds. During the measurements, the evaporator and condenser powers were also analyzed.

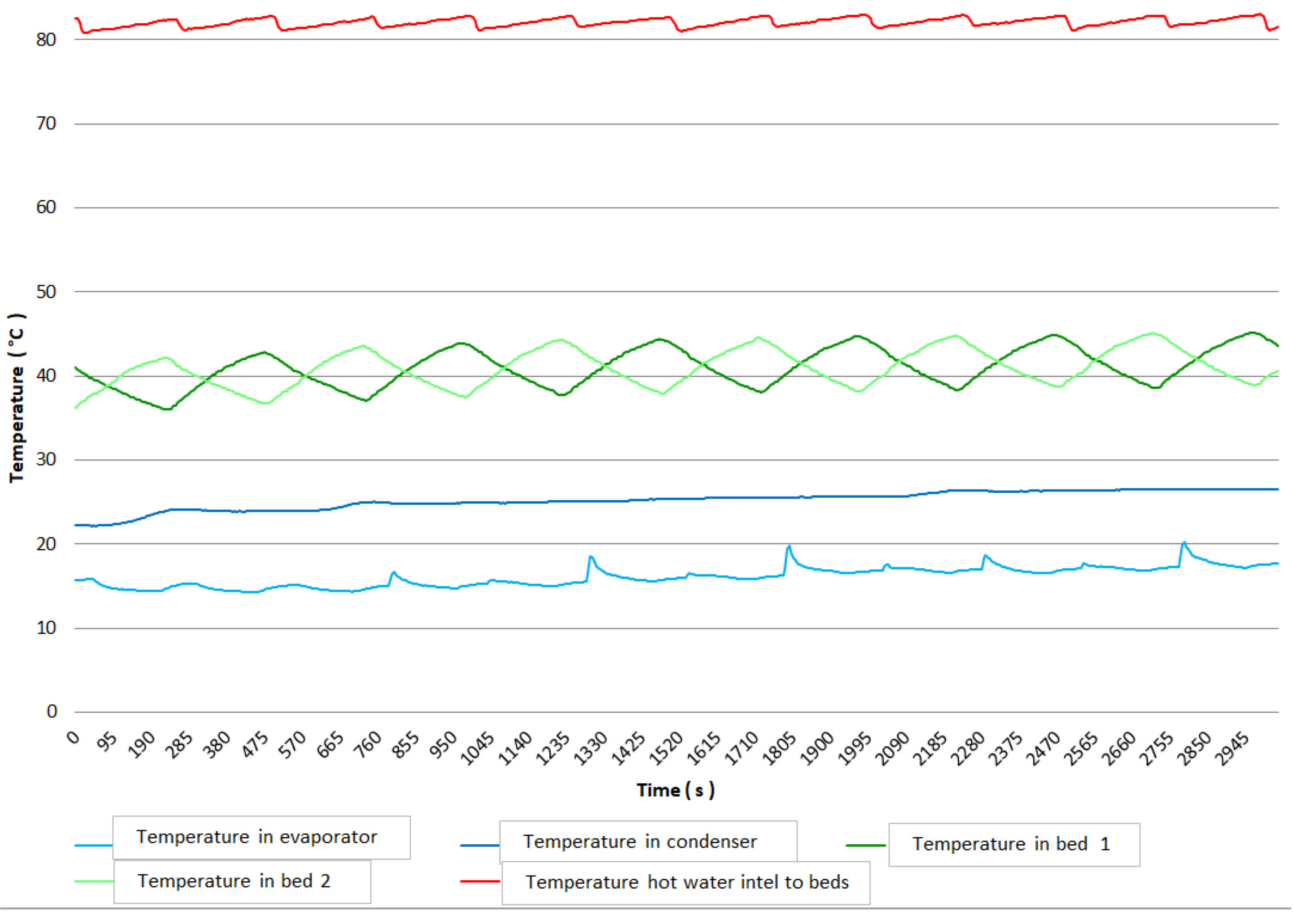

Figure 5. Changes in temperature in the adsorption chiller components during the testing.

Figures 7 and 8 show the effects of the temperature of hot water used during the desorption process, varying from 55 to $85^{\circ} \mathrm{C}$, on the values of the COP and SCP. The COP and SCP were defined according to previously published papers [23-25].

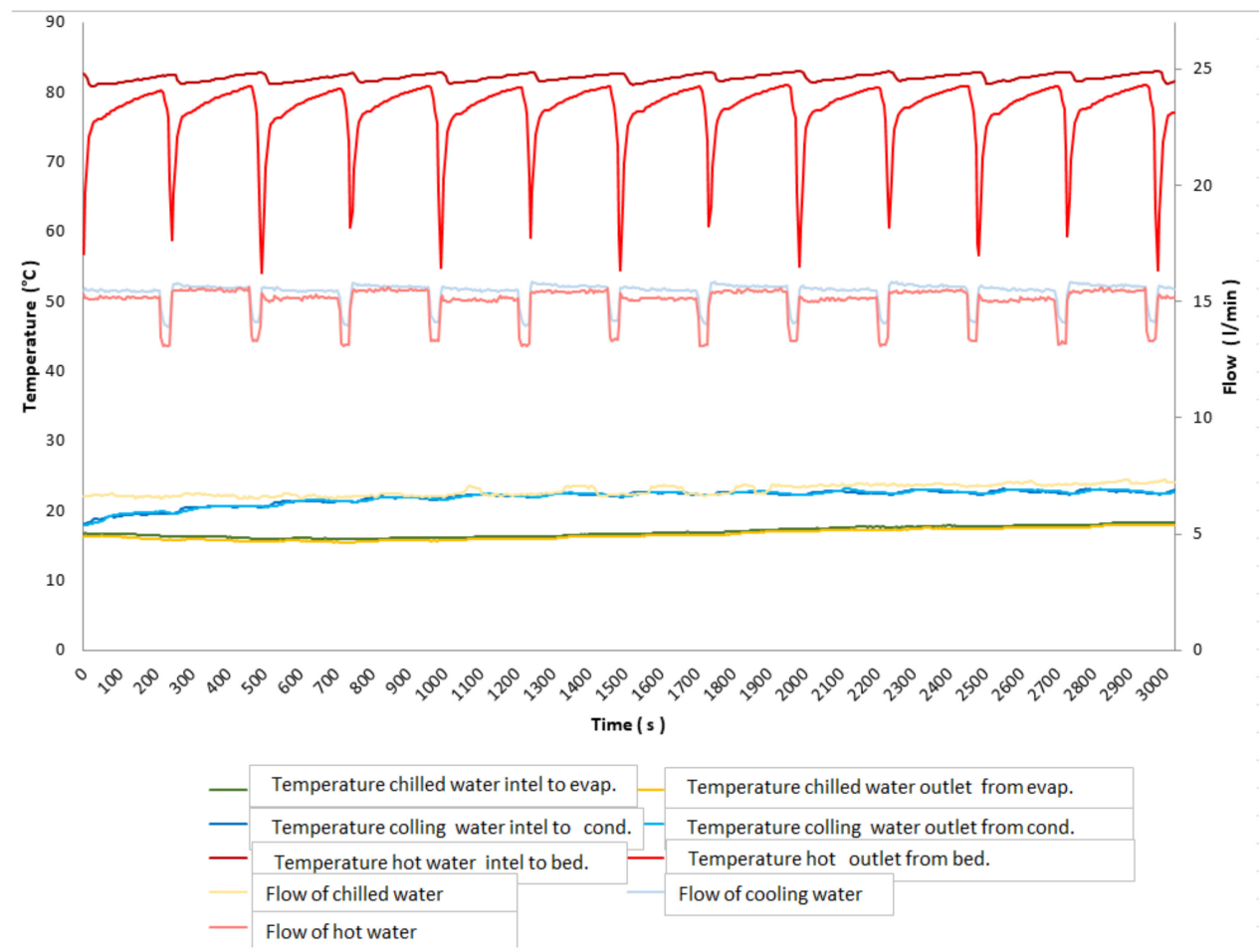

Figure 6. Temperature and water flow rate distribution in the adsorption chiller circuits. 


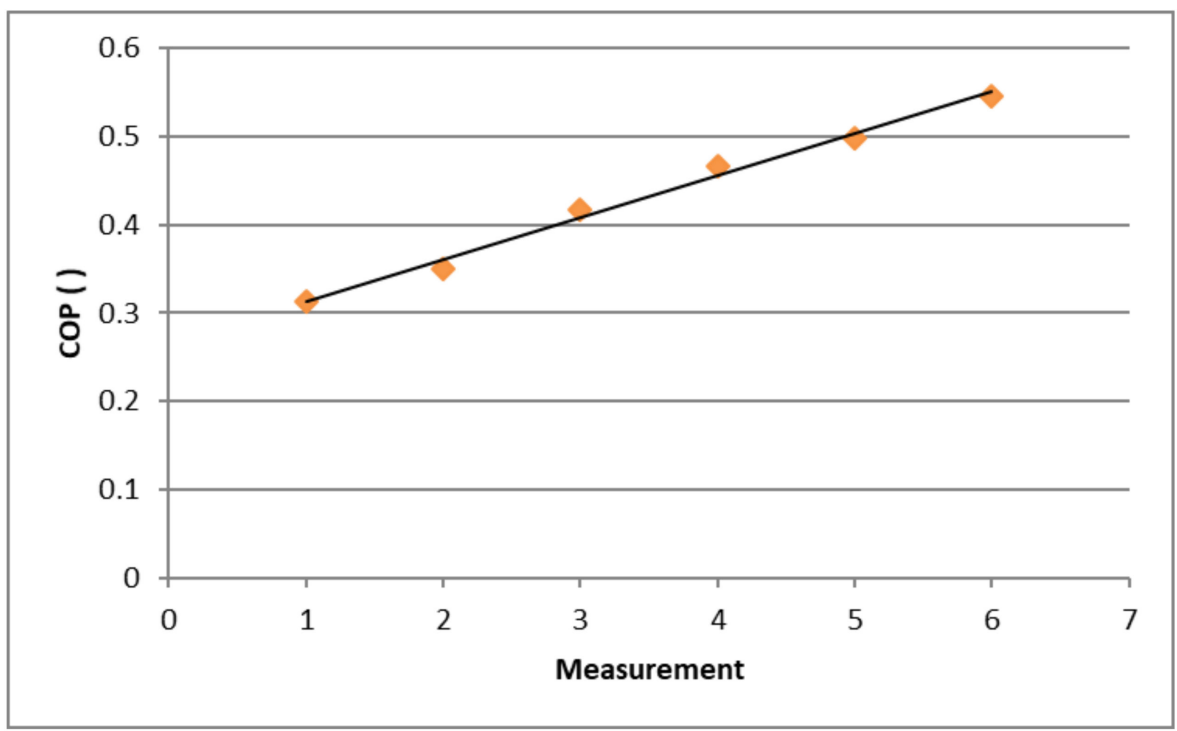

Figure 7. Effect of hot water temperature on COP value.

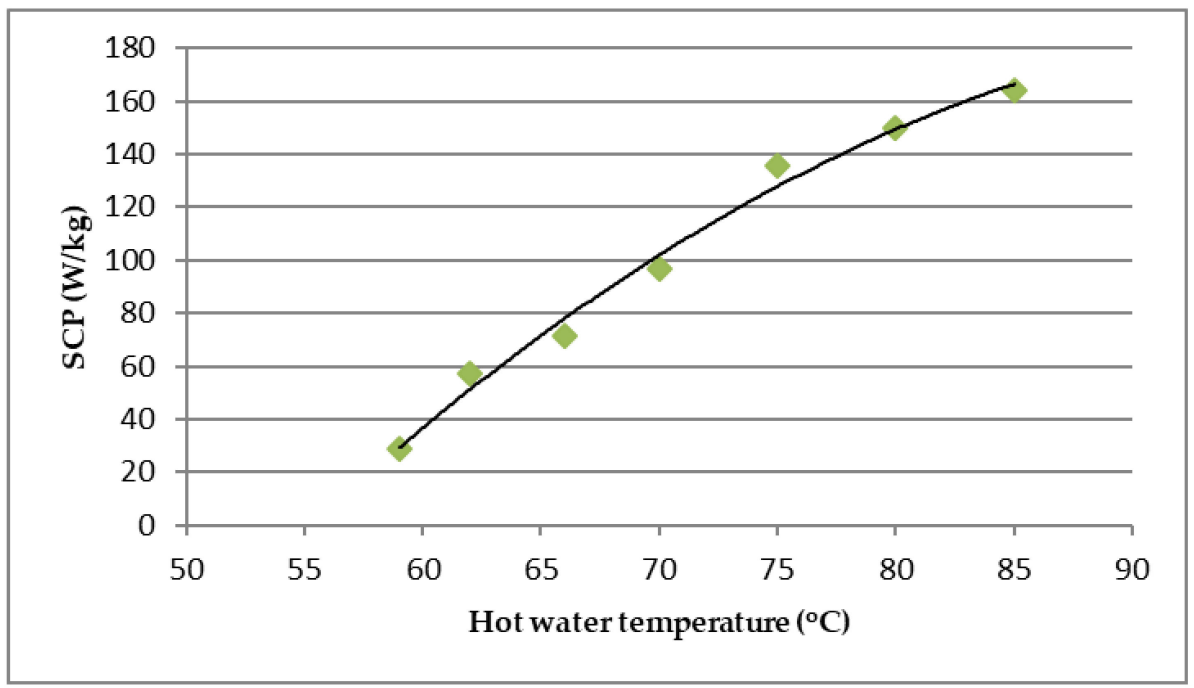

Figure 8. Effect of hot water temperature on SCP value.

The increase of the hot water temperature allowed increasing the desorption, because the intensity of desorption increased with increasing of the temperature and to increase the heat exchange rate inside the bed, because greater temperature difference intensified the heat transfer between the hot water and the bed. Therefore, both of these phenomena made the desorption process faster and allowed reducing the desorption time in the bed.

Based on the experimental data, it was found that as the temperature of the chiller feed water increased from $55^{\circ} \mathrm{C}$ to $85^{\circ} \mathrm{C}$, an increase in the COP value from 0.35 to 0.5 was observed. Figure 8 shows the dependence of the SCP value on the temperature of the hot water supplied to the chiller. It was observed that the SCP value changed with increasing hot water temperature from $27 \mathrm{~W} / \mathrm{kg}$ of sorbent to approx. $160 \mathrm{~W} / \mathrm{kg}$ of sorbent. Thus, the experimental data indicated that the hot water temperature had a significant effect on increasing the SCP and COP values. An increase in the hot water temperature caused an acceleration of the desorption process and, thus, an increase in the rate of release of water contained in the silica gel. Changes in temperature resulted in shorter desorption times and faster regeneration of the bed. Since the adsorption chiller can be supplied with heat from solar collectors, then, taking into account the results obtained in the first stage of the study, it was decided to carry out the tests in the second stage for hot water temperatures 
of $65^{\circ} \mathrm{C}$ and $80^{\circ} \mathrm{C}$, for groups 1,2 , and 3 . Figures $9-11$ show the dependence of the COP of the device and condensate flow on the adsorption and desorption times and on the cooling and chilled water temperatures for hot water temperatures of $80^{\circ} \mathrm{C}$ and $65{ }^{\circ} \mathrm{C}$. The detailed study design is presented in Table 4.

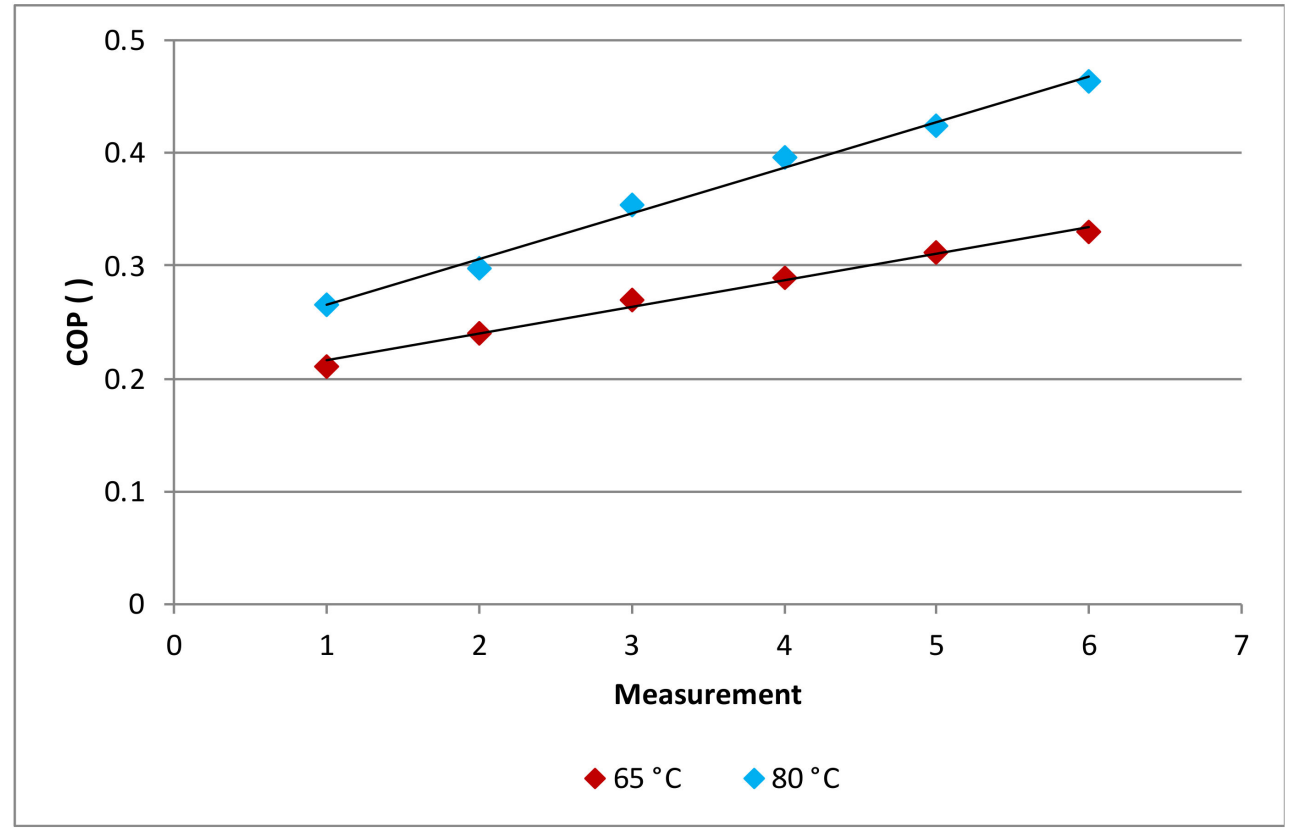

(a)

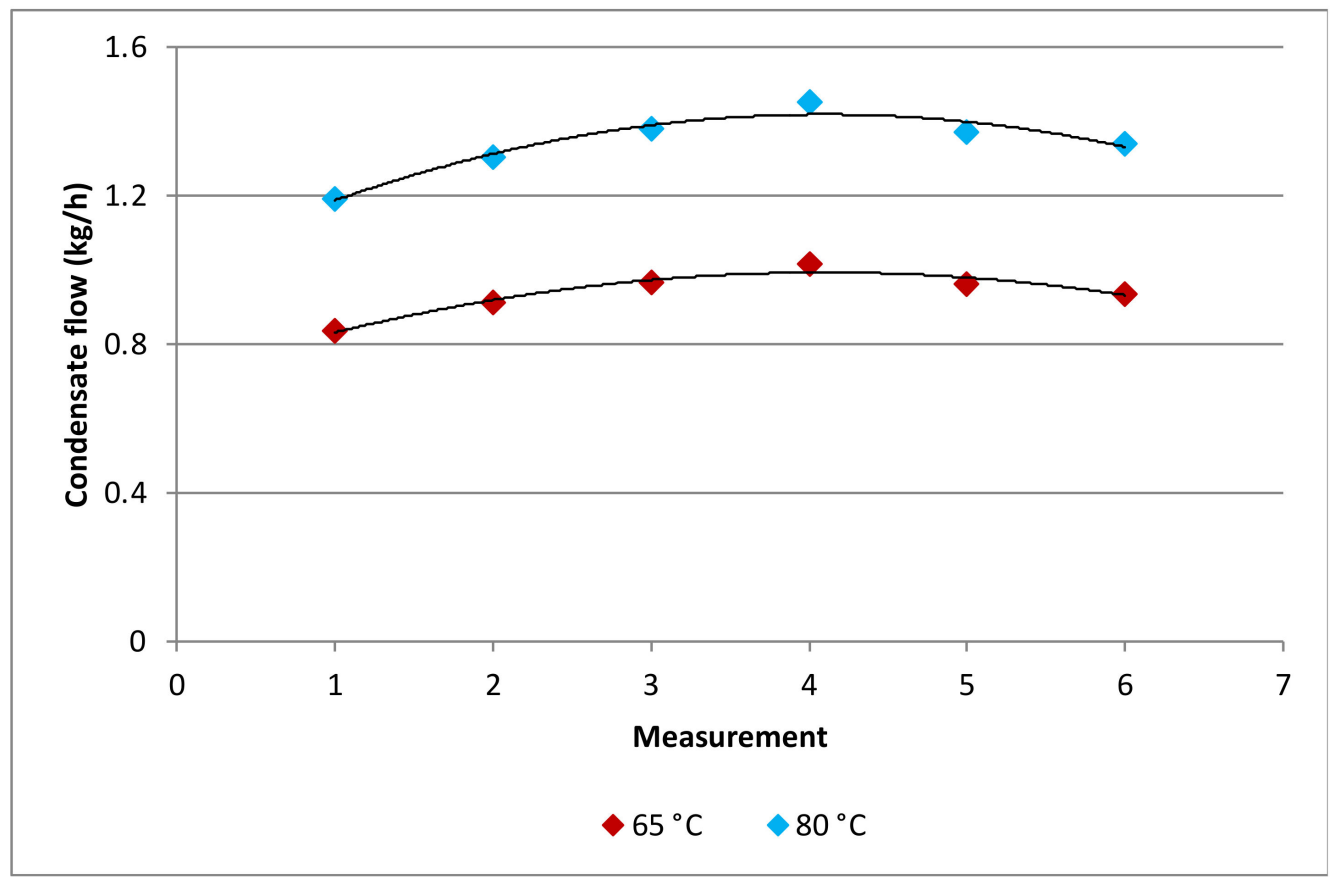

(b)

Measurement point (cycle times [s] for regen/sorption/heat rec./regen./sorption/ heat rec.):(1) $50 / 150 / 30 / 50 / 150 / 30$ (2) 50/250/30/50/250/30 (3) 50/350/30/50/350/30 (4) 50/450/30/50/450/30 (5) $50 / 550 / 30 / 50 / 550 / 30$ (6) 50/700/30/50/700/30

Figure 9. Experimental testing results in GROUP 1 at the hot water temperatures of $80{ }^{\circ} \mathrm{C}$ and $65{ }^{\circ} \mathrm{C}$ : (a) COP; (b) condensate flow. 


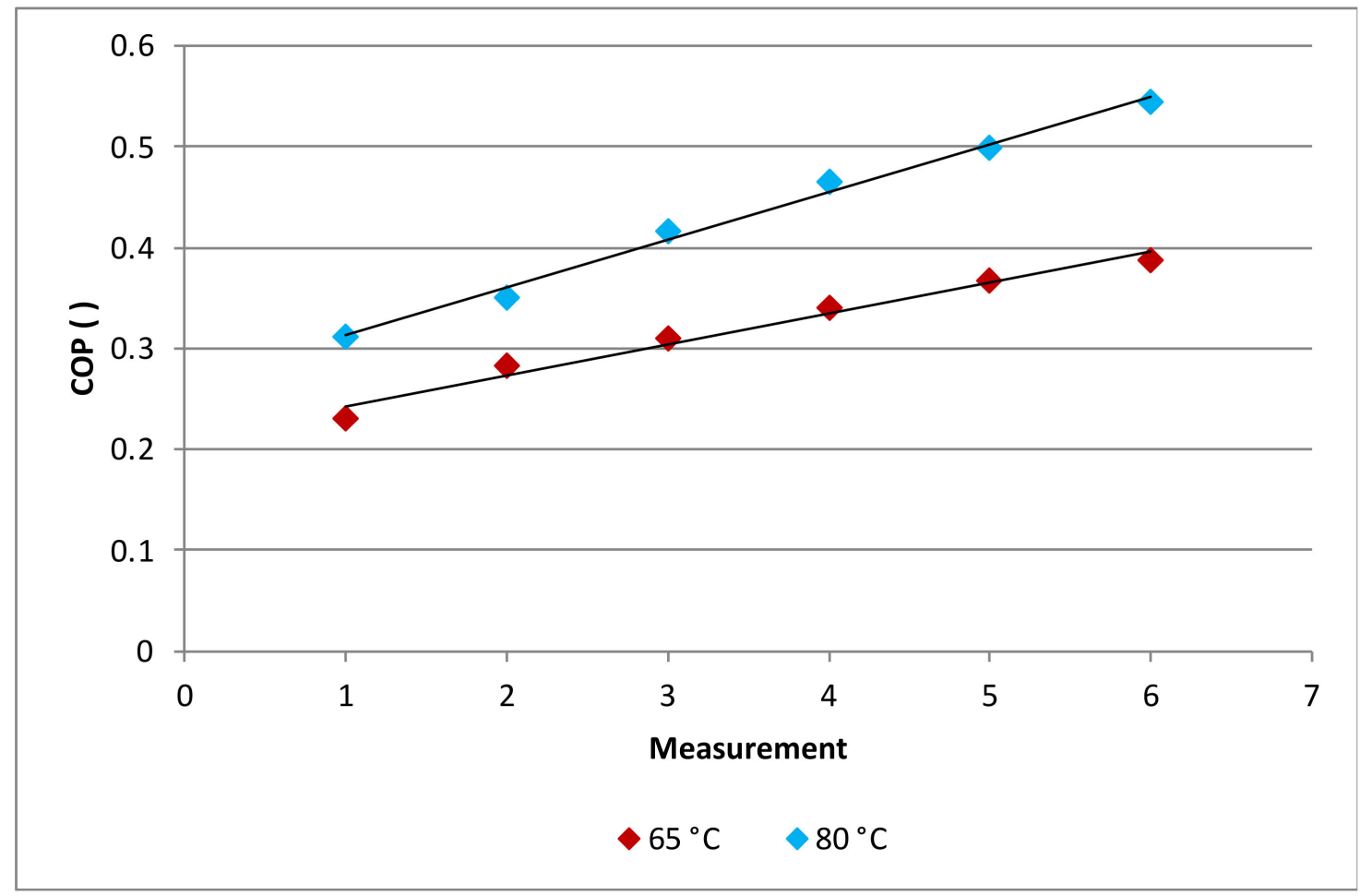

(a)

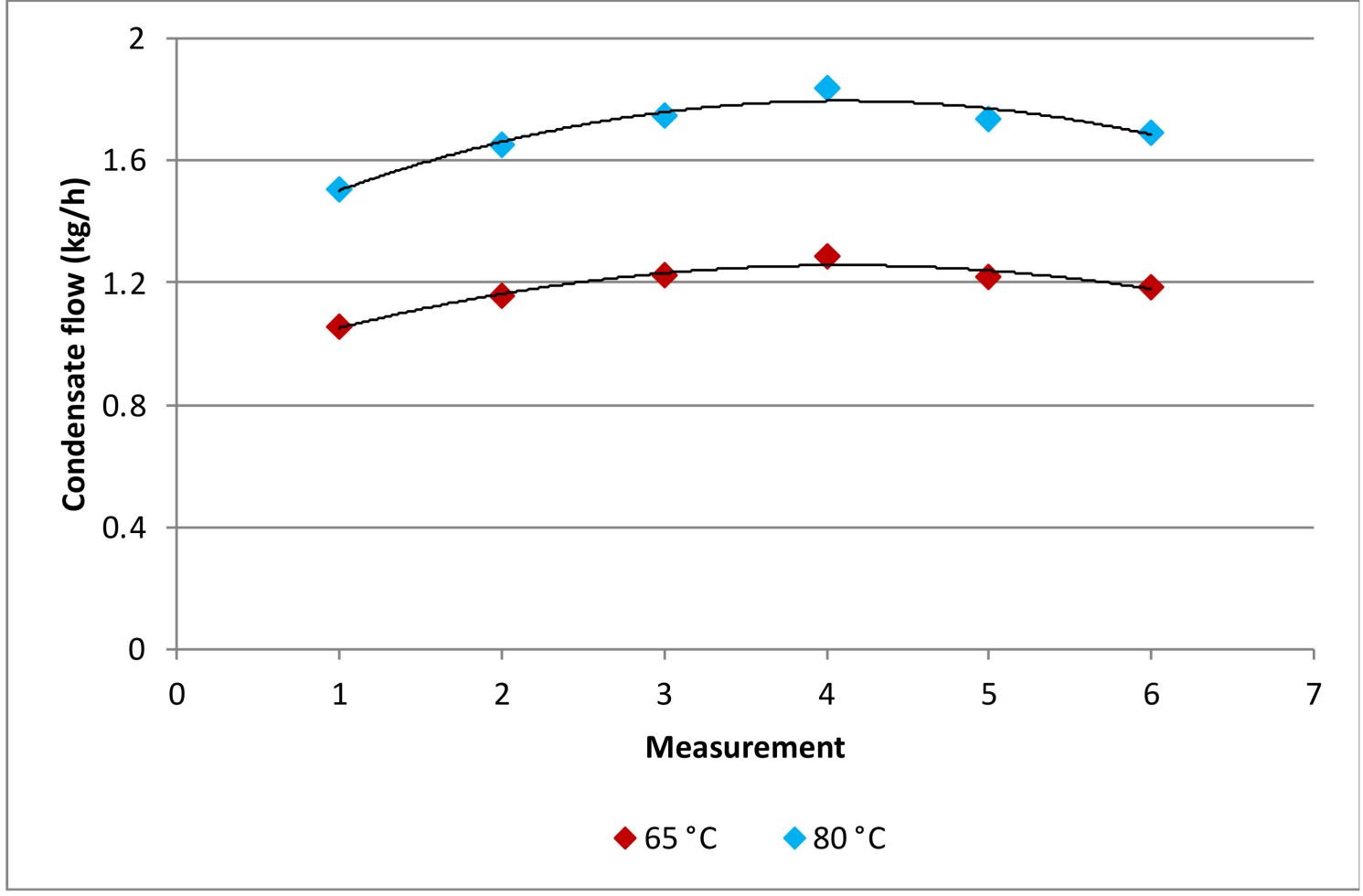

(b)

Measurement point (cycle times [s] for regen/sorption/heat rec./regen./sorption/ heat rec.): (1) $50 / 150 / 30 / 50 / 150 / 30$ (2) 50/250/30/50/250/30 (3) 50/350/30/50/350/30 (4) 50/450/30/50/450/30 (5) $50 / 550 / 30 / 50 / 550 / 30$ (6) 50/700/30/50/700/30

Figure 10. Experimental testing results in GROUP 2 at the hot water temperatures of $80^{\circ} \mathrm{C}$ and $65{ }^{\circ} \mathrm{C}:(\mathbf{a}) \mathrm{COP}$; (b) condensate flow. 


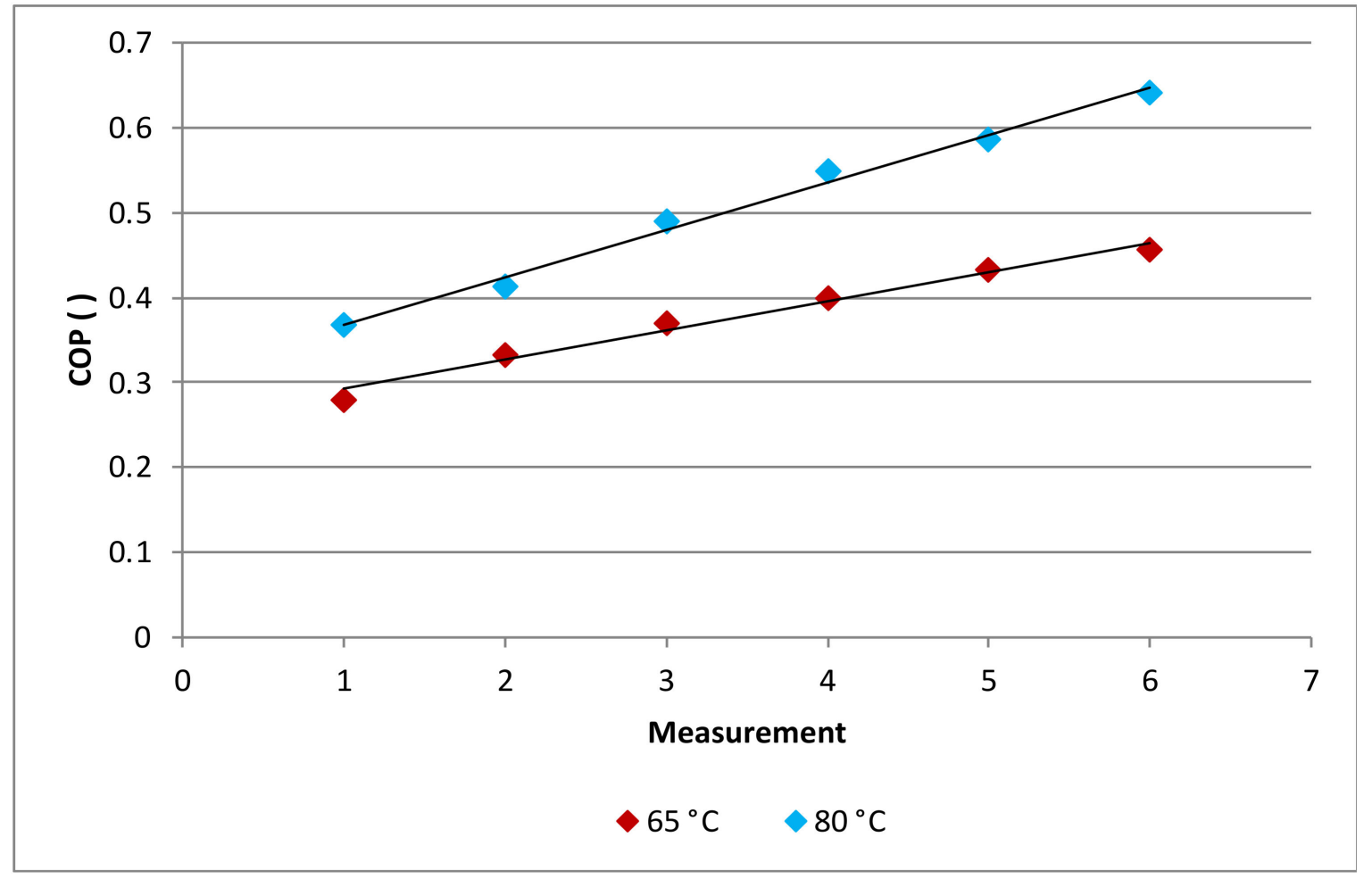

(a)

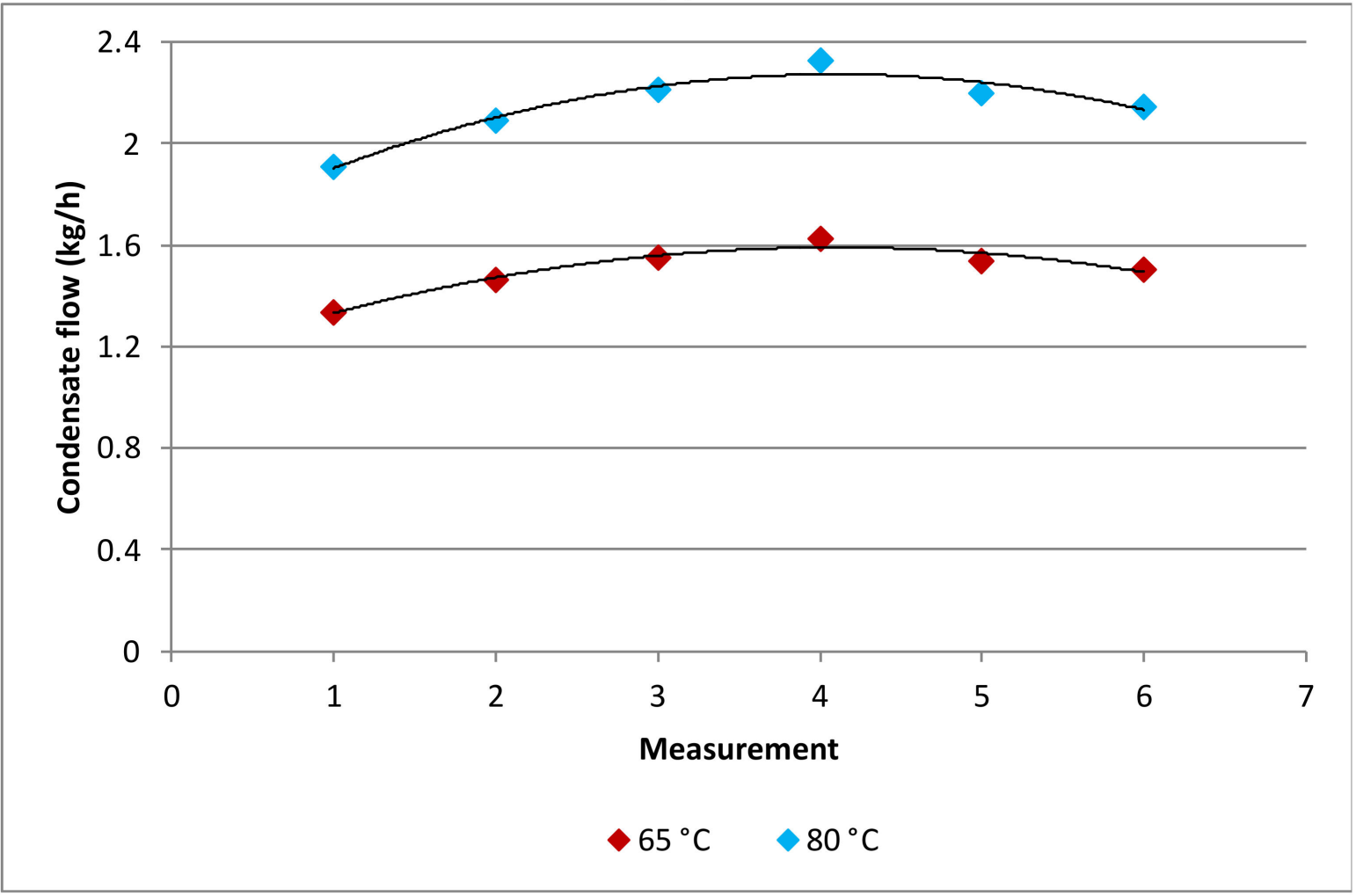

(b)

Measurement point (cycle times [s] for regen/sorption/heat rec./regen/sorption/ heat rec.): (1) $50 / 150 / 30 / 50 / 150 / 30 \quad$ (2) 50/250/30/50/250/30 (3) 50/350/30/50/350/30 (4) 50/450/30/50/450/30 (5) $50 / 550 / 30 / 50 / 550 / 30$ (6) 50/700/30/50/700/30

Figure 11. Experimental testing results in GROUP 3 at the hot water temperatures of $80^{\circ} \mathrm{C}$ and $65^{\circ} \mathrm{C}$ : (a) COP; (b) condensate flow. 
When analyzing the experimental results, it can be stated that the COP value of the adsorption chiller depended on many factors. The COP value was most significantly affected by the temperature of the hot water flowing into the device. Based on the testing, it was determined that the device had the highest efficiency at a temperature of approx. $80{ }^{\circ} \mathrm{C}$. In the case of desalination, condensate and concentrated brine accumulated in external tanks, which means that brine to be replenished in the device, and this caused a drop in the COP value. Based on the experimental data, it might be concluded that the cycle time of $150 \mathrm{~s}$ was too short, because the heat exchanger was not heated enough and a not-complete water release in the desorption process was observed. On the other hand, during the adsorption process, not all the water vapor produced in the evaporator was adsorbed, which limited the evaporator power and the value of the unit COP and the amount of condensate production. When the adsorption/desorption time increased above $550 \mathrm{~s}$ to $700 \mathrm{~s}$, a further increase in the COP of the device was observed because the heat loss decreased, but the distillate production rate decreased due to the sorption intensity decrease. Based on the experimental data for the two-bed chiller, it can be concluded that a cycle time of $450 \mathrm{~s}$ was the most promising because a good balance between high COP and intensive distillate production was maintained. The obtained experimental data on an adsorption chiller with desalination function obtained from installation at AGH University of Science and Technology Energy Centre were consistent with the work of $\mathrm{Ng} \mathrm{K.C.} \mathrm{et} \mathrm{al.} \mathrm{[16]} \mathrm{investigating} \mathrm{experimental} \mathrm{pilot} \mathrm{adsorption} \mathrm{chiller} \mathrm{with} \mathrm{desalination}$ function operated in four-bed mode. This device was characterized by a much higher distillate production of about $3 \mathrm{~m}^{3} /$ tonne per day and a different design of heat exchangers as well as the amount of sorbent used for testing. Tests presented by $\mathrm{Ng} \mathrm{K.C} \mathrm{[16]} \mathrm{were}$ carried out at varying temperatures of hot water and chilled water, but the authors did not analyze the effect of changing the temperature of the cooling water on the operation of the unit. The results showed that when the temperature of chilled water and hot water used for the desorption process increased, also an increase in distillate production was observed. For example, for hot water temperature of $85^{\circ} \mathrm{C}$ for ice water of $15{ }^{\circ} \mathrm{C}$ and $25^{\circ} \mathrm{C}$, an increase in distillate production capacity from about $4 \mathrm{~m}^{3} /$ day to $5.5 \mathrm{~m}^{3} /$ day was observed. Similar trends were observed for experimental studies carried out in this study. The results of the tests on the effect of the duration of the adsorption and desorption phases of the device for chilled water temperatures from $15^{\circ} \mathrm{C}$ to $25^{\circ} \mathrm{C}$ and cooling water temperatures from $20^{\circ} \mathrm{C}$ to $30^{\circ} \mathrm{C}$ indicated that sorption time had a significant effect on the COP value of the device, as well as on the amount of condensate produced. In the case of sorption and desorption times from 150 to $350 \mathrm{~s}$, the device had a low COP value, which ranged from 0.18 to 0.48 , and a low value of condensate production, which, under these conditions, was $0.834-2.21 \mathrm{~kg} / \mathrm{h}$. The reason for this is that the duration of the adsorption and desorption phases was too short for the materials used, as well as for the size and design of the adsorption bed. During the experiment it was observed that the increasing of sorption time influenced the increase of COP value, while, at the same time, condensate production during desalination process was decreased.

The highest value of COP was for a sorption time of $700 \mathrm{~s}$ for all variants and was up to 0.64 for a temperature of chilled water of $25^{\circ} \mathrm{C}$ and a temperature of cooling water of $30^{\circ} \mathrm{C}$; the lowest COP for $700 \mathrm{~s}$ for a temperature of chilled water of $15^{\circ} \mathrm{C}$ and a temperature of cooling water of $20^{\circ} \mathrm{C}$, it was $\mathrm{COP}=0.32$. It was observed that with increasing sorption time, the amount of produced condensate decreased. For a sorption time of $700 \mathrm{~s}$ for temperature of chilled water of $25^{\circ} \mathrm{C}$ and a temperature of cooling water of $30^{\circ} \mathrm{C}$, stream condensate was $2144 \mathrm{~kg} / \mathrm{h}$; the lowest condensate production was observed at $700 \mathrm{~s}$ for temperature of chilled water of $15^{\circ} \mathrm{C}$, and for the temperature of cooling water of $20^{\circ} \mathrm{C}$, it was $1.18 \mathrm{~kg} / \mathrm{h}$.

The best performance was achieved with adsorption and desorption cycle times of $450 \mathrm{~s}$. For this time, the device achieved the highest condensate production for all groups; but the highest amount of condensate production was observed for a temperature of chilled water of $25^{\circ} \mathrm{C}$, a temperature of cooling water of $30^{\circ} \mathrm{C}$, and temperature of hot water 
of $80{ }^{\circ} \mathrm{C}$, which was $2.32 \mathrm{~kg} / \mathrm{h}$ and the COP value was 0.547 . The lowest condensate production for $450 \mathrm{~s}$, where the temperature of chilled water was $15^{\circ} \mathrm{C}$, the temperature of cooling water was $20^{\circ} \mathrm{C}$, and the temperature of hot water was $65^{\circ} \mathrm{C}$, it was $1.01 \mathrm{~kg} / \mathrm{h}$ and the COP value was 0.29 .

The sorption and desorption processes were most dynamic in this bed during the first $450 \mathrm{~s}$, and beyond this time the process was much less intensive and, therefore, the COP value and the amount of condensate produced both decreased. This can also be seen in the diagrams of pressure and temperature distribution in the beds where excessive cooling and overheating of the bed were observed, as well as an increase in the temperature of the chilled water in the evaporator. With such long times for the adsorption and desorption phases, the effect of water evaporation was minimal, because of which the temperature of chilled water in the evaporator rose, which also contributed to an increase in pressure in the evaporator. For the optimal operation of the device, an important aspect was also the selection of appropriate temperatures of the working fluids in the entire system. Based on the measurement data obtained, it can be stated that the highest COP values and the highest distillate production was achieved for a condenser inlet temperature of $30{ }^{\circ} \mathrm{C}$ and an evaporator outlet chilled water temperature of $25^{\circ} \mathrm{C}$ for a hot water temperature of $80{ }^{\circ} \mathrm{C}$. The amount of chilled water produced dropped slightly, by about $10 \%$, for a hot water temperature of $65^{\circ} \mathrm{C}$.

\section{Conclusions}

The experimental results suggest that there are many factors that influence the efficiency of sorption processes and, consequently, the COP value and the amount of condensate produced by the adsorption refrigeration system. First of all, the temperature of the hot feed water had a huge impact. The higher the hot water temperature, the higher the COP and SCP values achieved by the device. For the system used in the tests, the COP reached a maximum of approx. 0.64 for operation with desalination function. The system operated with higher COP values in a closed circuit, i.e., without desalination. Other factors that determined the COP value and the amount of desalinated water produced were the temperature of the condenser cooling water and the temperature of the chilled water. The results of the tests showed that for the maximum efficiency of desalination, these temperatures were $30{ }^{\circ} \mathrm{C}$ and $25^{\circ} \mathrm{C}$ for both hot water temperatures for adsorption and desorption cycle times of $450 \mathrm{~s}$. The maximum condensate flow in the experimental tests did not exceed the value of $2.32 \mathrm{~kg} / \mathrm{h}$.

The COP value of the device was also strongly influenced by the times of the particular working cycles of the device, which depended on the adsorbents and adsorbates used, their quantity, and the bed structure. When changing the structure of the bed used in the device or the type and amount of sorbent, each time the optimal duration of adsorption and especially desorption cycles should be determined experimentally to maximize the COP and the amount of desalinated water produced. The examined device achieved its maximal condensate production with sorption cycle times of $450 \mathrm{~s}$, while the best COP was achieved in this chiller with a sorption cycle time of $700 \mathrm{~s}$.

Author Contributions: Conceptualization, K.S.; methodology, K.S. and Ł.M.; formal analysis, K.S. and Ł.M., investigation, K.S.; resources, K.S. and Ł.M.; data curation, K.S. and Ł.M.; writing-original draft preparation, K.S. and Ł.M.; writing-review and editing, K.S. and Ł.M.; supervision, K.S.; project administration, K.S.; funding acquisition, Ł.M. Both authors have read and agreed to the published version of the manuscript. All authors have read and agreed to the published version of the manuscript.

Funding: The paper was funded by a subsidy for research from the Faculty of Energy and Fuels, number 16.16.210.476.

Data Availability Statement: Not applicable.

Conflicts of Interest: The authors declare no conflict of interest. 


\section{References}

1. $\quad$ EFBW EU Bottled Water Statistics; Key Statistics. Available online: https:/ / www.efbw.org (accessed on 18 October 2019).

2. UNICEF \& WHO Progress on Household Drinking Water, Sanitation and Hygiene, 2000-2017. 2019, p. 140. Available online: https:/ / www.unicef.org/reports/progress-on-drinking-water-sanitation-and-hygiene-2019 (accessed on 1 June 2019).

3. EEA Signals 2018-Water Is Life. Available online: https://www.eea.europa.eu/signals/signals-2018-content-list (accessed on 24 November 2019).

4. $\quad$ Pitzer, L.R. Leaving No One Behind; Watercare: London, UK, 2013; Volume 96, ISBN 9789231003097.

5. Thu, K.; Ng, K.C.; Saha, B.B.; Chakraborty, A.; Koyama, S. Operational strategy of adsorption desalination systems. Int. J. Heat Mass Transf. 2009, 52, 1811-1816. [CrossRef]

6. Bitaw, T.N.; Park, K.; Kim, J.; Chang, J.W.; Yang, D.R. Low-recovery, -energy-consumption, -emission hybrid systems of seawater desalination: Energy optimization and cost analysis. Desalination 2019, 468, 114085. [CrossRef]

7. Voutchkov, N. Energy use for membrane seawater desalination-current status and trends. Desalination 2018, 431, 2-14. [CrossRef]

8. International Institute of Refrigeration. 29th Informatory Note on Refrigeration Technologies: The Role of Refrigeration in the Global Economy; IIR: Paris, France, 2015; Volume 16.

9. Alsaman, A.S.; Askalany, A.A.; Harby, K.; Ahmed, M.S. A state of the art of hybrid adsorption desalination-cooling systems. Renew. Sustain. Energy Rev. 2016, 58, 692-703. [CrossRef]

10. Jalihal, P.; Venkatesan, R. Advanced desalination technologies. In W: Sustainable Water and Wastewater Processing; Galanakis, C.M.R., Agrafioti, E., Eds.; Elsevier Publishing: Amsterdam, The Netherlands, 2019; pp. 93-131.

11. Ng, K.C.; Thu, K.; Kim, Y.; Chakraborty, A.; Amy, G. Adsorption desalination: An emerging low-cost thermal desalination method. Desalination 2013, 308, 161-179. [CrossRef]

12. Ghaffour, N.; Missimer, T.M.; Amy, G.L. Technical review and evaluation of the economics of water desalination: Current and future challenges for better water supply sustainability. Desalination 2013, 309, 197-207. [CrossRef]

13. World Population Prospects 2019: Highlights, New York, United Nations, Department of Economic and Social Affairs 2019. Available online: https:/ / population.un.org/wpp/ (accessed on 1 January 2019).

14. Sarai Atab, M.; Smallbone, A.J.; Roskilly, A.P. A hybrid reverse osmosis/adsorption desalination plant for irrigation and drinking water. Desalination 2018, 444, 44-52. [CrossRef]

15. Youssef, P.G.; Mahmoud, S.M.; AL-Dadah, R.K. Performance analysis of four bed adsorption water desalination/refrigeration system, comparison of AQSOA-Z02 to silica-gel. Desalination 2015, 375, 100-107. [CrossRef]

16. Ng, K.C.; Thu, K.; Chakraborty, A.; Saha, B.B.; Chun, W.G. Solar-assisted dual-effect adsorption cycle for the production of cooling effect and potable water. Int. J. Low-Carbon Technol. 2009, 4, 61-67. [CrossRef]

17. Zarzo, D.; Prats, D. Desalination and energy consumption. What can we expect in the near future? Desalination 2018, 427, 1-9. [CrossRef]

18. Shahzad, M.W.; Burhan, M.; Ang, L.; Ng, K.C. Energy-water-environment nexus underpinning future desalination sustainability. Desalination 2017, 413, 52-64. [CrossRef]

19. Nassrullah, H.; Anis, S.F.; Hashaikeh, R.; Hilal, N. Energy for desalination: A state-of-the-art review. Desalination 2020, 491, 114569. [CrossRef]

20. Eke, J.; Yusuf, A.; Giwa, A.; Sodiq, A. The global status of desalination: An assessment of current desalination technologies, plants and capacity. Desalination 2020, 495, 114633. [CrossRef]

21. Stefański, S.; Mika, Ł.; Sztekler, K.; Kalawa, W.; Lis, Ł.; Nowak, W. Adsorption bed configurations for adsorption cooling application. E3S Web Conf. 2019, 108. [CrossRef]

22. Elsayed, E.; AL-Dadah, R.; Mahmoud, S.; Anderson, P.; Elsayed, A. Experimental testing of aluminium fumarate MOF for adsorption desalination. Desalination 2020, 475, 114170. [CrossRef]

23. Sztekler, K.; Kalawa, W.; Nowak, W.; Mika, L.; Grabowska, K.; Krzywanski, J.; Sosnowski, M.; Al-Harbi, A.A. Performance evaluation of a single-stage two-bed adsorption chiller with desalination function. J. Energy Resour. Technol. 2020, 1-22. [CrossRef]

24. Sztekler, K.; Kalawa, W.; Nowak, W.; Mika, L.; Gradziel, S.; Krzywanski, J.; Radomska, E. Experimental study of three-bed adsorption chiller with desalination function. Energies 2020, 13, 5827. [CrossRef]

25. Sztekler, K.; Kalawa, W.; Mika, Ł.; Mlonka-Medrala, A.; Sowa, M.; Nowak, W. Effect of additives on the sorption kinetics of a silica gel bed in adsorption chiller. Energies 2021, 14, 1083. [CrossRef]

26. Saha, B.B.; Koyama, S.; Lee, J.B.; Kuwahara, K.; Alam, K.C.A.; Hamamoto, Y.; Akisawa, A.; Kashiwagi, T. Performance evaluation of a low-temperature waste heat driven multi-bed adsorption chiller. Int. J. Multiphase Flow 2003, 29, 1249-1263. [CrossRef]

27. Pan, Q.; Peng, J.; Wang, R. Experimental study of an adsorption chiller for extra low temperature waste heat utilization. Appl. Therm. Eng. 2019, 163, 114341. [CrossRef]

28. Kim, Y.D.; Thu, K.; Masry, M.E.; Ng, K.C. Water quality assessment of solar-assisted adsorption desalination cycle. Desalination 2014, 344, 144-151. [CrossRef] 